\title{
Study of Remu River Water Quality Using Dynamic Program
}

\author{
Lebrina Thenu, Nieke Karnaningroem
}

\begin{abstract}
Remu River has been a water resource for residents in Sorong City. Development in this city leads to water quality degradation of Remu River. Existing (2016) and prediction condition of Remu River in the next two years were defined by the behavior of BOD, COD, Fe, and DO that proceed using a dynamic program, STELLA 9.1.3. Study area involved six sampling points. Simulation results showed that BOD, COD, and Fe concentrations tend to increase in the next two years, even BOD and COD concentrations at several sampling points were higher than water quality standard, according to Government Regulation No. 82/2001. Meanwhile, DO concentration was below the limit in $4^{\text {th }}$ to $6^{\text {th }}$ sampling points. The pollution control strategy was conducted by setting up three scenarios: (1) procurement of Waste Water Treatment Plant (WWTP), (2) river sediment dredging, and (3) combination of both scenario. Combination of sediment dredging and procurement of WWTP scenario estimated to reduce BOD concentration to 89.82\%, COD concentration to $\mathbf{8 7 . 0 2} \%$, and increase DO concentration to $19.07 \%$. So, the $3^{\text {rd }}$ scenario was determined as the best strategy to improve Remu River water quality, although Fe concentration cannot be controlled as it comes from nature.
\end{abstract}

Keyword — water quality, Program STELLA, polluted, WWTP, dredging.

\section{INTRODUCTION}

$\mathrm{R}$ emu River is the main water resource in Sorong City. Remu River plays essential roles as a resource for PDAM (water utilities); daily necessities (bathing, washing, and restrooms); and water transportation in Sorong city. According to the results of the monitoring and evaluation conducted by Balai Pengelola Daerah Aliran Sungai Remu Ransiki of West Papua Province in 2010 and based on water quality monitoring results undertaken by Dinas Lingkungan Hidup dan Pertanahan of West Papua Province in 2015, land clearing along the watersheds, population growth and settlement development around Remu River contribute to several problems: degradation of land productivity, sediment and erosion escalation, and river contamination [5]. Some parameters of water quality are above quality standard. However, this study selected four parameters: BOD, COD, Fe, and DO. Remu River is surrounded by settlement, offices, restaurants, and lodging, which generate domestic waste contaminants, including organic and inorganic materials. Parameters of BOD, COD, and $\mathrm{Fe}$ in water require oxygen (DO) for the oxidation process. Thus, the interaction between BOD, COD, Fe, and DO parameters can influence the behavior of Remu River, which describes the condition of Remu River.

Simulation using a dynamic program of STELLA 9.1.3 was conducted by inputting secondary data of the parameters in the last four years to predict Remu condition in the next two years. The dynamic system is an alternative methodology in predicting the behavior of a real system. It also studies the possibilities which occur during the application of various scenarios or policies into a model. A fundamental and important understanding of dynamic systems methodology is on changeable behavior of the objects, very depending on time, as a result of influences from the system itself or the environment around the system [1].

This study aimed to establish a prediction of Remu River condition in the next two years and set up

Lebrina Thenu and Nieke Karnaningroem are with Department of Environmental Engineering, Faculty of Civil, Environmental and GeoEngineering, Institut Teknologi Sepuluh Nopember, Surabaya, 60111, Indonesia. E-mail: n.karnaningroem@gmail.com. strategy control by observing the behavior of BOD, $\mathrm{COD}, \mathrm{Fe}$, and DO parameters.

\section{METHOD}

This research was started by collecting secondary data of Water Quality Monitoring in 2013-2016, morphology data, population data in Manoi district and Sorong district, and lodging occupancy rate data from BPS Sorong city. Meanwhile, primary data collected were the concentration of $\mathrm{BOD}, \mathrm{COD}, \mathrm{Fe}, \mathrm{DO}$, river flow, river depth, and temperature.

Both of the secondary and primary data were processed using STELLA 9.1.3 dynamic program to determine the condition of Remu River by observing the behavior of BOD, COD, Fe, and DO. These parameters were affected by human activities (settlements, offices, restaurants, and hotels or lodgings). Data processing took several stages: (1) Dynamic model formulation (causal loop and model structure); (2) Running model included Calibration, Verification, Validation, Existing Simulation; (3) Prediction Simulation.

Dynamic model formulation, according to StreeterPhelps modeling was limited to two phenomena (see Eq.1), (1) Process of reducing dissolved oxygen (deoxygenation) due to bacterial activities during organic materials degradation and (2) Process of improving dissolved oxygen (reoxygenation) occurred from river flow turbulence $[1,12]$.

$$
\begin{aligned}
& \frac{\mathrm{dDO}}{\mathrm{dt}}=\mathrm{K}_{1} \underbrace{\left(\mathrm{DO}_{\text {sat }}-\mathrm{DO}_{\text {measu }}\right.}_{\text {Reoxygenation }})-(\underbrace{\mathrm{K}_{2} \cdot \mathrm{BOD}_{\text {measured }}+\mathrm{K}_{3} \cdot \mathrm{COD}_{\text {measured }}+\mathrm{K}_{4} \cdot \mathrm{Fe}_{\text {measured }}(1)}_{\text {Deoxygenation }} \\
& \text { Where: } \\
& \mathrm{K}_{1} \quad=\text { reoxygenation constant rate, } \text { day }^{-1} \\
& \mathrm{DO}_{\text {sat }}=\text { concentration of saturated dissolved } \\
& \text { oxygen, } \mathrm{mg} / \mathrm{l} \\
& \mathrm{DO}_{\text {measured }}=\text { concentration of dissolved oxygen at the } \\
& \text { chosen sampling point }(\mathrm{mg} / \mathrm{l}) \\
& \mathrm{K}_{2}, \mathrm{~K}_{3}, \mathrm{~K}_{4}=\text { deoxygenation constant rate }\left(\text { day }^{-1}\right) \\
& \mathrm{BOD}_{\text {measured }}=\text { concentration of } \mathrm{BOD} \text { at the chosen } \\
& \text { sampling point }(\mathrm{mg} / \mathrm{l}) \\
& \mathrm{COD}_{\text {measured }}=\text { concentration of COD at the chosen } \\
& \text { sampling point }(\mathrm{mg} / \mathrm{l})
\end{aligned}
$$




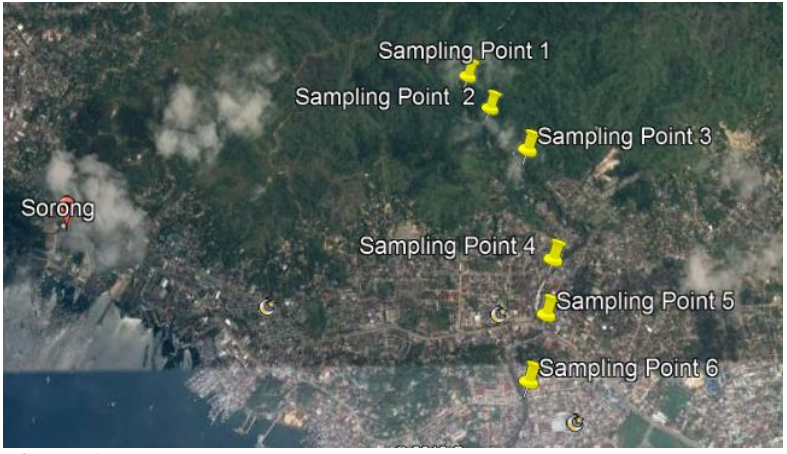

Figure 1. Sampling Points Location.

$\begin{aligned} & \mathrm{Fe}_{\text {measured }}= \text { concentration of } \mathrm{Fe} \text { at the chosen } \\ & \text { sampling point }(\mathrm{mg} / \mathrm{l})\end{aligned}$

\section{RESULTS AND DISCUSSION}

Sampling location, as shown in Figure 1, consists of six points started from RM1 (upper water pump) to RM6 (the bridge at Jend. Sudirman Street). Causal loops (Figure2) and model structures (Figure 3) were formed arranged based on mass balance theory, deoxygenation, reoxygenation, BOD decay, COD decay, Fe decay and the conditions around Remu River.

Secondary data and primary data were inputted into the model structure by entering values and equations as follows:

Potential pollution load (PBP) from settlements, offices, restaurants, and hotels on the environmental aspect of model structure used equation 2. City equivalent ratios were 1 and river reaching coefficient was 0.85 . BOD emission factor of domestic waste was $40 \mathrm{~g} /$ day, COD of domestic wastewater was $55 \mathrm{~g} / \mathrm{day}$. BOD emission factor of hotel wastewater was 55 gr/day/visitor, COD of hotel wastewater was 75.6 $\mathrm{gr} /$ day/visitor. BOD emission factor of restaurant wastewater was $17 \mathrm{gr} /$ day/visitor, COD of restaurant wastewater was $25.2 \mathrm{gr} /$ day/visitor [13]:

PBP Domestic Wastewater $=$ Population $x$ Emission Factor $x$ City Equivalent Ratio $x$ River Reaching Coefficient

Reoxygenation rate was influenced by the difference between saturated DO and DO at the sampling point and reoxygenation rate constant $(\mathrm{Ka})$, as stated in equation 3.

\section{Reoxygenation $=K a($ DOsat $-\mathrm{DO})$}

Deoxygenation rate was determined by BOD (CBOD and NBOD), COD, Fe, and sediment of organic materials (see Eq. 5). Kd value was assumed to be the same for BOD, and COD, which can be calculated by equation 4 [2], while the $\mathrm{kd}$ value of $\mathrm{Fe}$ was $0.0173 / \mathrm{min}$ $-0.1005 / \mathrm{min}$ [3]. The value of Kn was $0.1-0.5 /$ day [4]. [NH3-N] was $0.05-0.29 \mathrm{mg}$ MLVSS/ $\mathrm{mgNH}_{3}-\mathrm{N}$ [5]. SOD was assumed to be in the base of the river, which contains minerals [2] which has the lowest range of 0.05 $\mathrm{g} \mathrm{O}_{2} / \mathrm{m}^{2}$.day due to a high amount of $\mathrm{Fe}$ at the upstream.

$$
\mathrm{Kd}_{20} \quad=0.3 \times\left(\mathrm{H} / 8^{)-0,434}\right.
$$

Deoxygenation $=\left(K_{d} \cdot B O D_{\text {measured }}+K_{d}\right.$.COD $D_{\text {measured }}+$

$$
\left.K_{d} \cdot \mathrm{Fe}_{\text {measured }}\right)+K n \cdot N+S O D
$$

Mass transfer $=m D O(B O D$ or $C O D$ or Fe) $x Q / V(6)$
Furthermore, the calibration process was conducted by using trial and error value of several variables to obtain a model which is similarly close to the actual value,

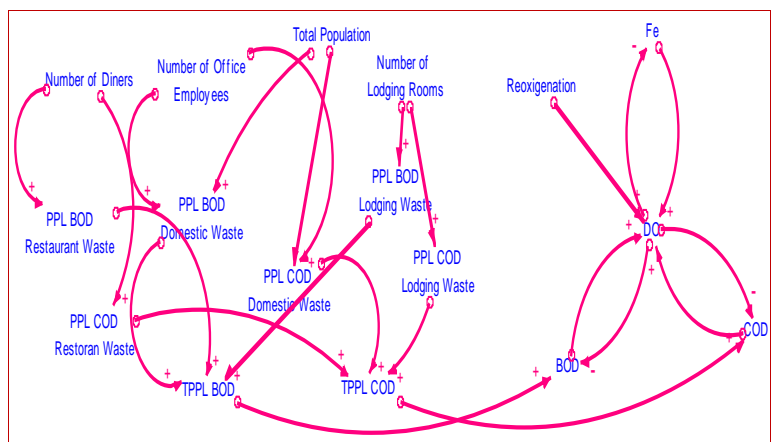

Figure 2. Causal Loop of BOD, COD, Fe, and DO Behavior in Remu River.

continued to a unit, and model structure verification. Model validation was performed by using a parameter behavior test and the Mean Absolute Percentage Error (MAPE) test. Behavior test for technical aspects between $\mathrm{BOD}, \mathrm{COD}, \mathrm{Fe}$, parameters was inversely proportional to DO parameter. When BOD, COD, and Fe parameters increased, DO parameter decreased, showed that it was correlated to the theory. The environmental aspect of behavior test also showed the accordance with the theory, stated that higher population leads to higher total pollution load. MAPE model output for the technical aspect of DO parameter showed good accuracy, which value was less than $10 \%$. The value shown by the model was the best estimation could be achieved from the provided data. Therefore, the model can still be used for simulation as its parameter test was compatible.

Prediction of Remu River in the next two years is presented in Figure 4 with the assumption that environmental condition around Remu River would remain the same.

Figure 4 revealed the concentrations of BOD, COD, and $\mathrm{Fe}$ gradually increase. The highest concentrations of BOD, COD, and Fe were $28.69 \mathrm{mg} / 1,87.34 \mathrm{mg} / \mathrm{l}$, and $2.30 \mathrm{mg} / \mathrm{l}$ on the $24^{\text {th }}$ month at sampling point 5 . Meanwhile, DO concentration was decreased; at sampling point 1 , it significantly got lower. Meanwhile, DO concentration was decreased; at sampling point 1 , it significantly got lower. Pollutant, which requires oxygen in the water, will rapidly decrease oxygen content [6]. An intense drop of dissolved oxygen at sampling point 1 showed high deoxygenation rate. Deoxygenation rate also described high concentrations of BOD, COD, and $\mathrm{Fe}$ which is in line with a theory said that water-soluble substances provide higher deoxygenation constant value and faster deoxygenation rates, whereas colloidal suspension has to wait for hydrolytic action before it diffuses into bacterial cells where oxidation can occur, so that its deoxygenation constant value becomes lower and reaction rate gets slower [7].

Varying degrees of oxygen depletion in each sampling point explained that the rate of deoxygenation depends on the characteristics of the waste (organic materials) and capability of organisms to utilize organic materials [8].

Prediction of Remu River condition in the next two years required pollution control. The primary strategy of environmental function recovery based on Law no. 32/2009 [9] about Environmental Protection and 


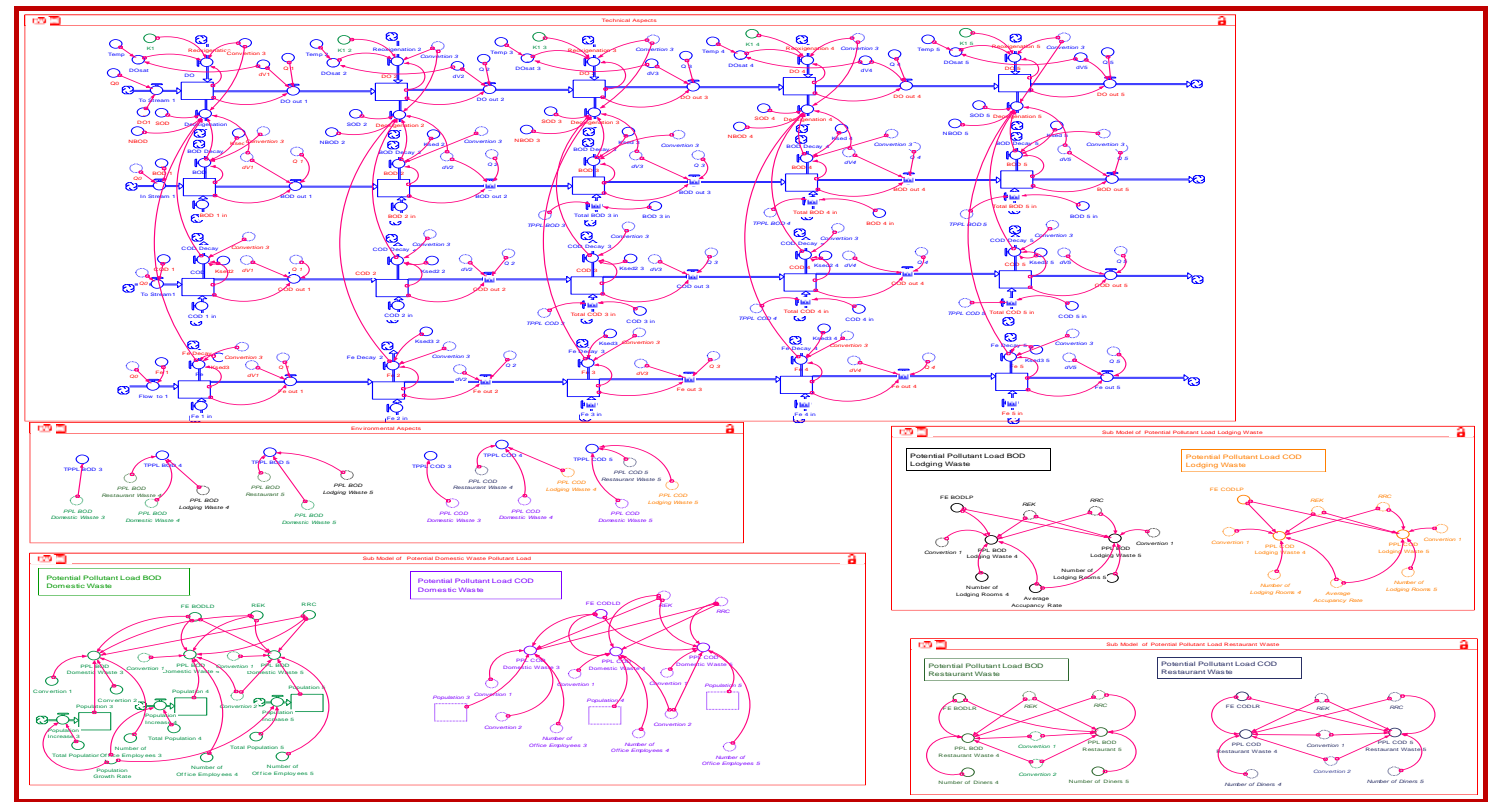

Figure 3. Model Structure of BOD, COD, Fe, and DO Behavior in Remu River.
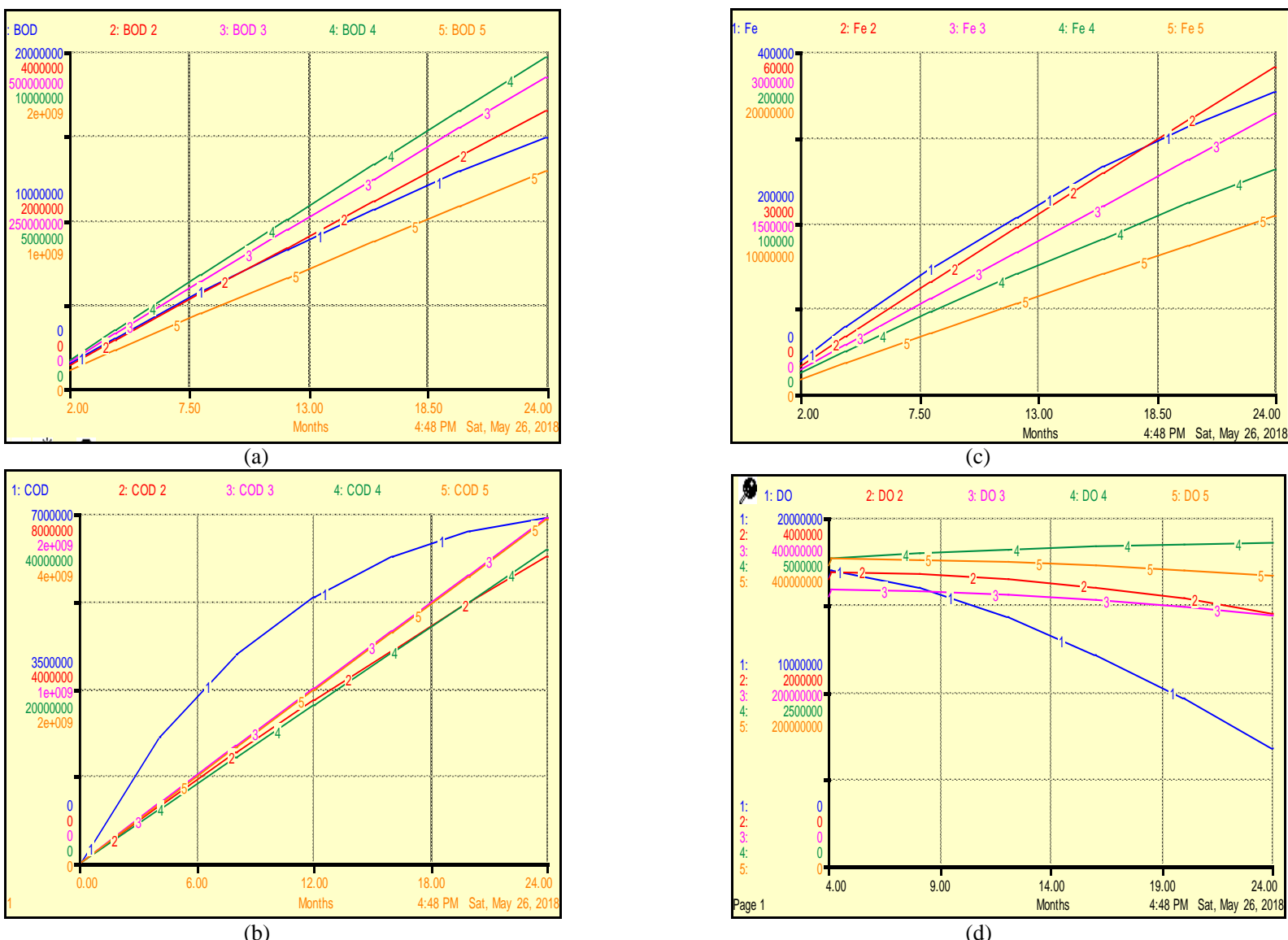

Figure 4. Simulation Result of Remu River Condition Prediction in the next two years for Parameter of BOD (a), COD (b), Fe (c) and DO(d)

Management would be restoration and removal of pollutant elements of pollutant sources. Several scenarios designed according to the previous concept:

Scenario 1: Procurement of WWTP in sampling points 3, 4,5 , and 6.

Scenario 2: Sediment dredging in sampling points $3,4,5$, and 6.

Scenario 3: Combination of scenarios 1 and 2.Simulation of scenario 1 and 3 informed depression of BOD and COD (see Figure 6 and 7) which were below water quality standard class II according to PP.82/2001 [10] i.e
$3 \mathrm{mg} / \mathrm{L}$ (BOD), 25mg/L (COD) at sampling points 3, 4, 5 and 6. DO concentration was above water quality standard class II (see Figure 5), $4 \mathrm{mg} / \mathrm{L}$. While in scenario 2, the concentration of parameter BOD at sampling point 5 and 6 were above water quality standard class II. Scenario 3 reduced BOD concentration to $89.82 \%$, COD concentration to $87.02 \%$, and increased DO concentration to $19.07 \%$. Because the function of WWTP is to remove pollutants with large dimensions, small and molecular and ionic. These pollutants are usually in the form of dissolved in water (dissolved or soluble), such as organic materials, minerals/metals, 


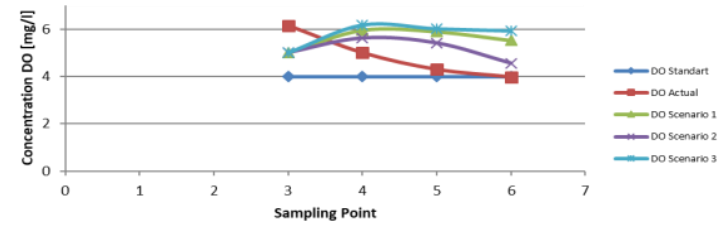

Figure 5. Parameter DO Simulation of Scenario 1,2, and 3.

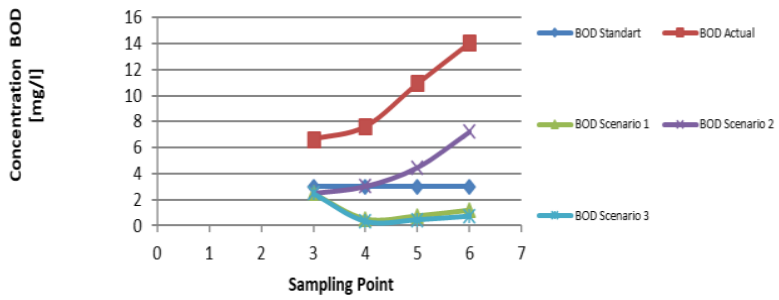

Figure 6. Parameter BOD Simulation of Scenario 1, 2, and 3.

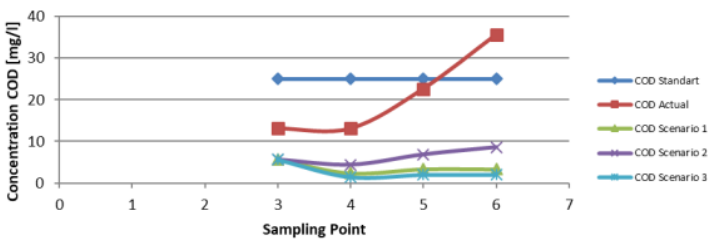

Figure 7. Parameter COD Simulation of Scenario 1, 2, and 3.

nutrients, and so on [11]. While dredging is chosen because it is based on equation 2.2, namely: $\left.\mathrm{L}=\mathrm{L}_{0} \cdot \mathrm{e}^{(-\mathrm{Kr}}(\mathrm{x} / \mathrm{u})\right)$. Where $\mathrm{Kr}$ is the decomposition coefficient plus the deposition coefficient [2], indicating that organic material entering the river other than decomposing also settles on the riverbed. For organic materials that have precipitated not to be suspended back into the water, the BOD and COD concentration values rise, then the sediment/sediment dredging is carried out. The decrease in BOD and COD concentrations in water bodies because the dredging process is assumed to be the same as the decrease in BOD and COD concentrations in the sedimentation process, which is $30-40 \%$ [12].

Meanwhile, Fe concentration in Remu River cannot be controlled as it comes from nature.

\section{CONCLUSION}

Remu River condition in the next two years would still be classified as polluted according to prediction results showed continues escalation of BOD, COD, and Fe which were above water quality standard of class II at several sampling points. The procurement of Waste
Water Treatment Plant (WWTP) to process domestic wastewater originated from activities around Remu River combined by the implementation of sediment dredging, can be applied from now on as an effort to prevent the occurrence of higher pollution in the future.

The existing model structure still needs to be improved to obtain data accuracy of parameter BOD, COD, and Fe.

\section{ACKNOWLEDGMENTS}

This paper would not have been possible without the financial support of Lembaga Pengelola Dana Pendidikan (LPDP) Kementerian Keuangan Republik Indonesia. I am especially indebted to Mr. Julian Kelly Kambu, ST, MSi, Chairman of Dinas Perlindungan dan Pengelolaan Lingkungan Hidup, who have been supportive of my career goals and who worked actively to provide me with the protected academic time to pursue those goals.

\section{REFERENCES}

[1] M. E. Aminullah and B. Soesilo, Analisis Sistem Dinamis Yogyakarta: UMJ Press, 2001

[2] S. C. Chapra, Surface-water-quality modeling. Waveland Press 2008 .

[3] R. Institut Teknologi Bandung., D. Roosmini, and S Notodarmojo, Journal of mathematical and fundamental sciences., vol. 39, no. 1-2. 2007.

[4] R. V. Thomann and J. A. Mueller, Principles of surface water quality modeling and control.

[5] T. D. Reynolds and P. A. Richards, Unit operations and processes in environmental engineering. PWS Pub. Co, 1996.

[6] A. K. De, Environmental chemistry. New Age International, 2010

[7] C. N. Sawyer, P. L. McCarty, and G. F. Parkin, Chemistry for environmental engineering and science.

[8] H. Kawashima and M. Suzuki, "NUMERICAL SIMULATION MODEL FOR PREDICTION OF BOD REMOVAL RATE IN STREAMS," Water Pollut. Res. Control Bright., pp. 1003-1014, Jan. 1988.

[9] Kementerian Lingkungan Hidup Republik Indonesia, UU Nomor 32 Tahun 2009 Tentang Perlindungan dan Pengelolaan Lingkungan Hidup - Referensi HAM. Jakarta, Indonesia: Kementerian Lingkungan Hidup, 2009.

[10] P. R. Indonesia, PENGELOLAAN KUALITAS AIR DAN PENGENDALIAN PENCEMARAN AIR. Indonesia, 2001, pp. 1155-1167.

[11] A. F. Assomadi and A. Masduqi, Operasi dan Proses Pengolahan Air. Surabaya: ITS Press, 2016.

[12] S. R. Qasim, Wastewater Treatment Plants : Planning, Design, and Operation, Second Edition. 